\title{
Failure Factors of ERP Projects in an Iranian Context
}

\author{
Malahat Pouransafar ${ }^{1}$,Maral Cheperli ${ }^{1}$, Mohammad Reza Faraj Tabrizi ${ }^{2}$ \\ ${ }^{1}$ Advanced Informatics School (AIS) - Universiti Teknologi Malaysia (UTM), Kuala Lumpur, Malaysia \\ ${ }^{2}$ International Business School (IBS) - Universiti Teknologi Malaysia (UTM), Kuala Lumpur, Malaysia
}

\begin{abstract}
Implementing an information technology project is a very challenging task that needs several preparations such as assigning a professional project manager, receiving top management support, employee engagement ,etc. Same studies have been conducted about the success and failure factors of the enterprise resource planning (ERP) projects and several researchers concluded that the ERP projects are very vulnerable.This qualitative research is an attempt to summarize the most common failure factors of the ERP projects in Iranian manufacturing industries.
\end{abstract}

key words: ERP failure Factor, IT project Management.

\section{INTRODUCTION}

Enterprise Resource Planning (ERP) systems are defined as a computer- based information system that process transactions of an organization and simplify integrated and real-time planning, production and customer response [1]. The purpose of designing these systems is to deal with the fragmentation problem, because they offer a series of software modules to totalize and simplify internal processes to cover all functions of business [2]. By implementing ERP, organizations try to achieve visibility through business processes and playing a radical role in dynamic environments [3]. While ERP systems have a lot of advantages, but the major concern is the high failure proportion [4]. According to the researches done, 70\% of implanting ERP fails to carry expected benefits [5] and three quarters of these projects are not successful [6]. In 2010, the results of the Standish Group survey showed that just $37 \%$ of the projects were successful (coming in on time and on budget). $42 \%$ of these projects were over budgets, late, or have less features and functions than expected. And $21 \%$ of the projects considered as a complete failure, it means that these projects were canceled before completing or never had been used after delivery. For more, more than $50 \%$ of the projects were cost $189 \%$ of their original estimates (Fister Gale, 2011).

ERP implementation difficulties in developing countries are different from those in developed and industrialized countries, while imagination anticipated that different and various countries face similar problems and challenges that associated with ERP package-organization misalignments [7] and [8]. As an ERP software designed and developed in industrialized countries and the structures and processes of the system designed by their technology, so the primary functional misalignments will occur between western ERP systems and demands of developing societies' companies. So, trying to adopt foreign ERP systems tend to failure of implementing these systems in developing countries [9].

Some of the major challenges that organizations face by ERP adoption are the level of BPR (Business Process Re-engineering), customization, and change management needed to fit best with their ERP system. In contrast, some organizations prefer to adopt less risky approaches like vanilla (this approach keeps BPR at the minimum level, and instead of customization, follow the major functions and processes of ERP) [5] . Selecting vanilla or other approaches, whether it is a small or large organization, a careful Project Management (PM) and a loyal team are required for ERP implementation [9].

Implementation of ERP systems is affected by several failure factors [10]. Unfortunately, the greatest numbers of researchers prefer to work on critical success factors (CSF) and fewer of them tend to work to find critical failure factors (CFF). It is said that from 1998 to 2007, only 6\% of all published or presented articles on ERP were discussed about CSFs [11] .On the other hand, in the same period, articles related to CFF of ERP implementation were accounted for less than one percent. It is important to consider that research projects about reviewing and analyzing of ERP CFFs play a major role in avoiding the previous mistakes [12] .

\section{A. General Issues}

\section{Problem Statement}

A survey that is conducted to gather some data from IT practitioners about the ERP system, argues that around $85 \%$ of the ERP users are fully satisfied from ERP and even some of the users declared that it is impossible for them to continue without ERP [13].

But, the majority of ERP projects is failing due to several reasons. Some of the projects left uncompleted and the rest terminated without any applicable function. There are several reasons for failure in 
ERP projects such as huge overhead cost that mainly caused by improper scope definition or sluggish progress in project execution [14].

Several studies claim that one of the major factors that contribute to success or failure of the ERP projects is management commitment and ultimate support. Nevertheless, the contribution of the rest stakeholders is vital [15] . Doing an ERP project is always associated with high level of risk, extra cost as well as uncertainty [16].

To minimize the risks of the ERP projects, the organizations should be cautious in scope setting, resolve all the existed conflicts among stakeholders, focus on the human factor, motivate the employee to contribute in the projects (it could be facilitated by training, reward programs and proper appraisal model), identify a systematic process to manage change orders and avoid last minute changes, eventually learn how to deal with macro environmental issues with flexibility and scalability [17].

\section{B. Marin County, California SAP}

According to Panorama consulting solutions, the recent SAP project of Marin County, California with more than $\$ 30$ million investment is an example of ERP project failure. In spite of vast investment and enough budgets, the system Integrator is blamed for fraud, misrepresentation, providing wrong information to sign the contract, implementing improper software with high rate of error, hiring fresh consultants with inadequate working experience [18].

Another reference reveals some more date about this project .The Marin County as the project owner claims that the SAP system handed over partiality on 2006 with 50 percent functionality only! But the SAP system Integrator (Deloitte) claims that the system is 100\% applicable. Deloitte also a complaint against Marin County because of unpaid invoices [19].

\section{UK National Health System (NHS)}

The worst case of ERP failure happened to NHS UK. In 2002 the government of UK accepted to invest $£ 12$ billion to develop an ERP during one decade in order to record the health data of the Britain citizens, develop the electronic appointment booking and drug prescription system. But in spite of vast amount of investment the project failed simply because the implemented system was not tailored properly for the body of the enormous UK geographical and political system. The relevant authorities claim that implementing such an ERP was a mistake from beginning and further continuing with the system is equal to more and more failure [20].

\section{City Time Payroll System Project, New York}

This is a sample of an ERP disaster that caused a nightmare for both systems Integrator SAIC the subcontractor, Techno Dyne! The project budget was initially planned in 2003 for a total amount of $\$ 60$ million in order to modernize the payroll system of New York City, but the real project cost extended to $\$ 760$ million in 2010 which amazed the employer so much. The employer argued that Techno Dyne has been participated in a fraud scheme and tapped around $\$ 80$ million from taxpayers. On the other hand, SAIC claimed for a total deficit of \$ 232 million [19] .

\section{E. ERP system of Epicor}

Another example of the failed ERP system is the case of Epicor and Ferazzoli. During 2009, Ferazzoli Imports from New England, USA (employer) reached an agreement WITH Epicor to implement the ERP project with a total budget of $\$ 184,444$ but the improper system design of Epicor caused additional cost for new software. So the project faced budget overrun for new software as well services meant to run the system and reached to $\$ 1$ million [21].

The Epicor case is more about failure in scope setting as well as cost control [20] .

\section{F. Oracle ERP systems for Montclair State University}

The subject of the contract was designing a PeopleSoft suite with Oracle to replace the 25-year-old set of legacy applications of Montclair State University. The parties signed the contract in 2009. Based on the contract, Oracle should receive around \$20 million for service implementation, software and support, but in 2010 Oracle claimed for extra $\$ 8$ million and warned to terminate all activities if the employer refuses to pay! After several negotiations the conflict was not resolved and eventually Montclair decided to terminate the contract with Oracle. It happened in November 2010 and consequently seven months later, the employer argued that Oracle has failed in all of the following contractual aspects:

- Delivery of services and functions of ERP based on the scope of the contract.

- Project time management

- Delivery of computer resources

- Deliver of proper and tested software 
- Project integration management (in framework of the contractual time, cost and quality terms and conditions)

- Project team turnover (in-out)

Due to the challenges with Oracle, Montclair claimed that they need to spend roughly $\$ 10$ to $\$ 20$ million to fulfill that ERP project. But, on the other hand Oracle argued that all problems arisen because of inadequate leadership in Montclair. System Integrator stated that top management of the university has no idea about that technology and eventually they do not know how to follow the project steps. It doesn't resolve their conflict and on December 2011 the university adds more complaints against Oracle. Those complaints were about misrepresentation and false statement by Oracle regarding deliverables of the project, time schedule, cost management system, as well as resources and capabilities of the contractor [14]. Eventually, Montclair failed to present enough reasons to win the lawsuit against Oracle and Oracle won the lawsuit partials [22].

\section{METHODOLOGY}

The authors conduct five intial interviews with ERP experts in Iran. Based on the results of the intial interviews, the following conceptual framework is designed as the basis of the open-ended questionnaire to collect qualitative data from 40 respendents in next step. The autors develop the conceptual framework based on the model of Human,Organization and Technology that previously used for several studies about IT security voulnerability [23]

The 40 respondents of this study are selected from IT, operation and production departments of the Iranian manufacturing industries.

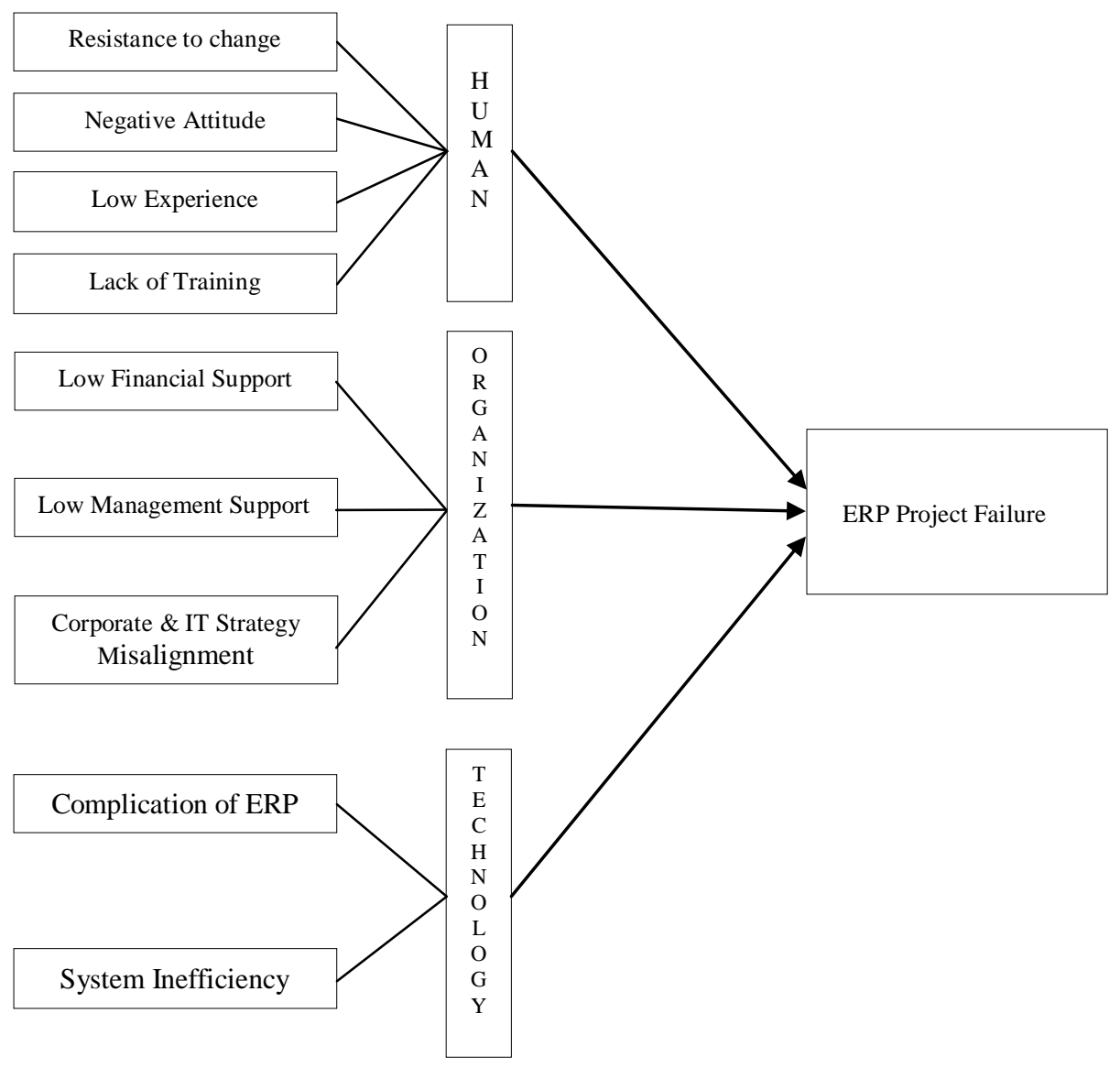

Figure 1: Conceptual Framework

\section{Findings AND ANALYSIS}

The following table 1 shows that the majority of the respondents belives on the impacts of human and organization factors on ERP failure (rather than technology factors). 
Table 1: Level of Support (Human-Organization-Technology Factors)

\begin{tabular}{|c|c|c|}
\hline Human & 39 & $97.50 \%$ \\
\hline Organization & 35 & $87.50 \%$ \\
\hline Technoloogy & 16 & $40.00 \%$ \\
\hline
\end{tabular}

The following Table 2 is an attempt to illustrate the opinions of the respondents more in detail.

Table 2: Level of Support (Detailed)

\begin{tabular}{|c|c|c|c|}
\hline \multirow{3}{*}{ Factor } & Item & $\begin{array}{c}\text { Noumber of } \\
\text { Support }\end{array}$ & Percentage \\
\hline \multirow{3}{*}{ Human } & Resistance to change & 31 & $77.50 \%$ \\
\cline { 2 - 4 } & Attitude & 7 & $17.50 \%$ \\
\cline { 2 - 4 } & Experience & 15 & $37.50 \%$ \\
\hline \multirow{3}{*}{ Organization } & Awareness/Training & 39 & $97.50 \%$ \\
\cline { 2 - 4 } & Financial Support & 32 & $80.00 \%$ \\
\cline { 2 - 4 } & Corporate \& IT Governance Alignment & 18 & $87.50 \%$ \\
\hline \multirow{2}{*}{ Technology } & Complication & 11 & $27.50 \%$ \\
\cline { 2 - 4 } & Inefficiency & 8 & $20.00 \%$ \\
\hline
\end{tabular}

The below barchart is another approach to show the significance of each factor on ERP projects of the Iranian production and manufacturing industries . As it is vividly illustrated in below, lack of sufficient training, lack of management support, lack of financial support as well as resistance to change are the most significant items that usually result in ERP projects vulnerability. On the otherhand, these are the major failure factors of ERP projects in Iranian manufacturing industries.

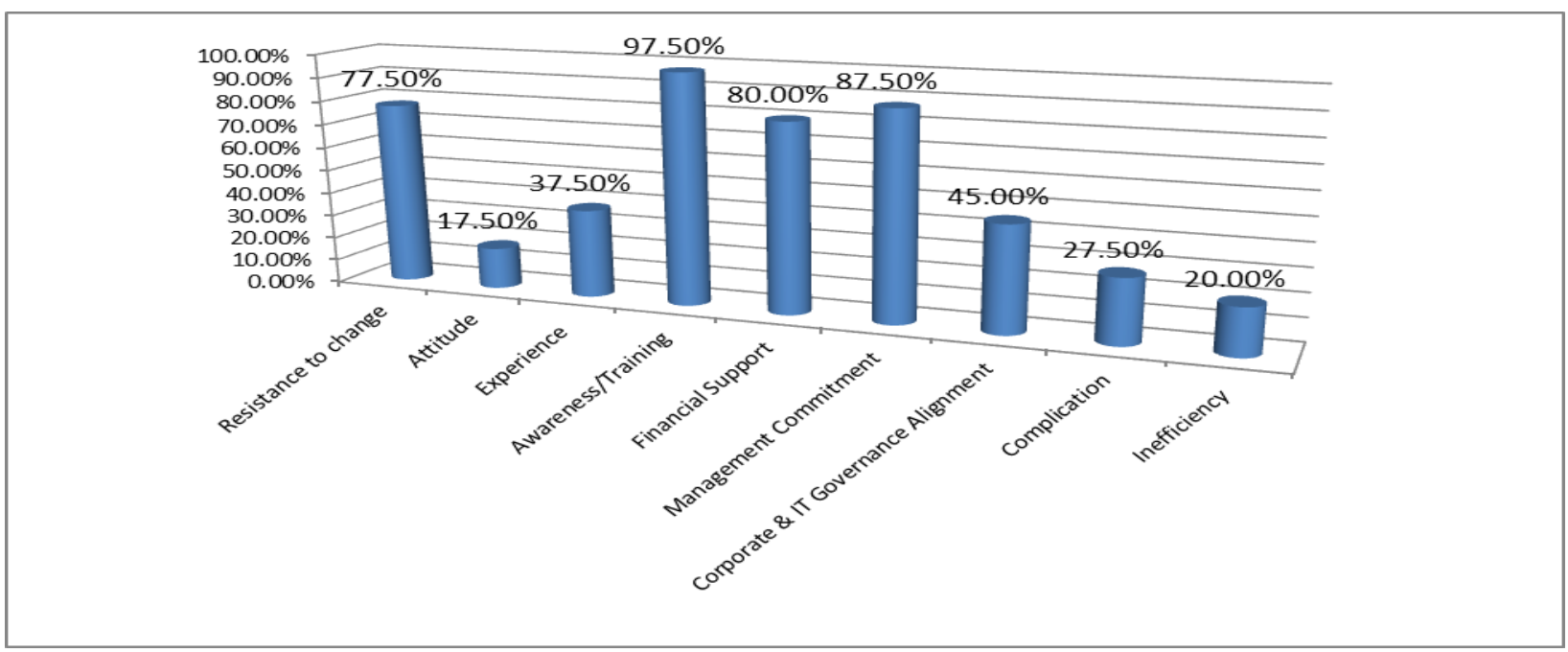

Figure 2- Overal Support of Respondents

The respondents also refer to the significance of maturity alignment between Corporate Governance and IT Govrnance.

One of the respondents argues that "I am always confused whether our ERP is really important or not! , the IT department has installed the software for us, trained us and we all know how to use it, but the head of department always ask me do my resource planning in another approach, somebody explain me about this conflict of interest, our target is to provide fast and reliable production, but how to do properly!"

The finding shows that the less than $40 \%$ of the respondents believe that lack of expreince is a significant failure factor of EPR projects in Iranian manufacturing industires. In fact, the majority of the respondents believe that the training and awareness programs are more important. On the respondents from operation department of a 
factory in Iran argues that "experience is important, but honestly I believe that even fresh graduated are also capable to contribute effectively in ERP project if the company train them effectively."

\section{CONCLUSION}

Several studies have been conducted about success factors of ERP projects and also some studies about failure factors of ERP in different industries. According to the findings of this study, it could be concluded that lack of sufficient training, lack of management support, lack of financial support and resistance of staff to change are the most challenging items that are considered as the major failure factors of ERP project in Iranian manufacturing industries.

\section{REFERENCES}

[1] D. O'Leary, "Enterprise Resource Planning Systems: Systems, Life Cycle, Electronic Commerce, and Risk," Cambridge University Press, 2000

[2] C. Koch, D. Slater and E. Baatz, "The ABCs of ERP," CIO, London, 2001.

[3] R. Malhotra and C. Temponi, "Critical decisions for ERP integration: small business issues," International Journal of Information Management, pp. 28-37, 2010.

[4] T. Davenport, "Putting the enterprise into the enterprise system," Harvard Business Review, p. 4, 1998.

[5] M. Al-Mashari, "Constructs of process change management in ERP context: a focus on SAP R/3," Proceedings of the Sixth Americas Conference on Information Systems, Long Beach, CA, 2000.

[6] V. Kumar, B. Maheshwari and U. Kumar, "An investigation of critical management issues in ERP implementation: emperical evidence from Canadian organizations," Technovation, p. 793-808, 2003.

[7] P. Soja, "Difficulties in enterprise system implementation in emerging economies: insights from an exploratory study in Poland," Information Technology for Development, p. 31-51, 2008.

[8] Z. Huang and P. Palvia, "ERP implementation issues in advanced and developing countries," Business Process Management Journal, p. 276-284, 2001.

[9] Y. Xue, "ERP implementation failures in China: case studies with implications for ERP vendors," International Journal of Production Economics, p. 279-295, 2005.

[10] E. Umble, R. Haft and M. Umble, "Enterprise resource planning: implementation procedures and critical success factors," European Journal of Operational Research, p. 241-257, 2003.

[11] Z. Huang, "A compilation research of ERP implementation critical success factors," Issues in Information Systems, p. 507-512, 2010.

[12] G. Pan, R. Hackney and S. Pan, "Information systems implementation failure: insights from prism," International Journal of Information Management, p. 259-269, 2008.

[13] T. Wailgum, "Why ERP Systems Are More Important Than Ever," 29 Jan 2008. [Online]. Available: http://www.cio.com. [Accessed 21 October 2012].

[14] C. Blazer, "MAJORITY OF ENTERPRISE RESOURCE PLANNING (ERP) PROJECTS FAIL - M-DCPS IS A RARE EXCEPTION," INFORMATION CAPSULE, vol. Vol. 1108, pp. 1-14, 2012.

[15] L. Bourne and D. H. Walker, "Visualising and mapping stakeholder influence," Management Decision, vol. 43, no. 5, pp. 649-660, 2005.

[16] B. Y. Chung, "AN ANALYSIS OF SUCCESS AND FAILURE FACTORS FOR ERP SYSTEMS IN ENGINEERING AND CONSTRUCTION FIRMS," Unpublished PhD Dissertation, Maryland, 2007.

[17] A. Salajegheh, F. Kimiaee and H. Ahmadian Yazdi, "Project Management, A Solution for ERP Failures," Mashhad, 20111.

[18] Panorama Consulting Solutions, "Lessons Learned From a Government ERP Failure," Panorama Consulting, Denver, 2012.

[19] C. Kanaracus, "Californian county to remove and replace SAP system," IDG News Service, 25 August 2010. [Online]. Available: http://www.computerworlduk.com/news/public-sector/3236898/californian-county-to-remove-and-replace-sap-system/. [Accessed 19 December 2012].

[20] C. Kanaracus, "10 Biggest ERP Software Failures of 2011," 20 December $2011 . \quad$ [Online]. Available: http://www.pcworld.com/article/246647/10_biggest_erp_software_failures_of_2011.html. [Accessed 19 December 2012].

[21] E. Kimberling, "ERP Failures and Lawsuits," 12 January 2011. [Online]. Available: http://www.backbonemag.com/Backblog/anappetite-for-destruction-the-erp-implementation-lawsuits-continue.aspx. [Accessed 18 December 2012].

[22] C. Kanaracus, "Computer World," 5 September $2012 . \quad$ [Online]. http://www.computerworld.com/s/article/9230928/Oracle_wins_partial_victory_in_school_s_ERP_project_lawsuit. [Accessed 21 October 2012].

[23] R. Werlinger, K. Hawkey and K. Beznosov, "Human, Organization, and Technological Challenges of Implementing IT Security in Organizations," Information Management \& Computer Seurity, vol. 17, no. 1, pp. 4-19, 2009. 